ISSN: 2036-5438

\title{
Subnational Constitutionalism: A Matter of Review
}

\author{
by
}

Giacomo Delledonne*

Perspectives on Federalism, Vol. 4, issue 2, 2012 


\section{Abstract}

Which is the meaning of constitutional review for a proper assessment of subnational constitutionalism? The essay tries to answer this question by means of comparative analysis. To do so, it considers both federal systems (the United States and Germany) and regional or autonomic systems (Italy and Spain). The analysis of organs and procedures allows to draw some conclusions: the presence of a system of constitutional review at the subnational level is a crucial element for the development of an autonomous, well-grown subnational constitutional law. However, subnational constitutional courts tend to have a more complicated relation with legislative and executive bodies, as less guarantees of independence or court-overturning amendments show. Finally, subnational constitutional courts tend to develop a quite interesting case law, whose experimental features sometimes anticipate major judicial trends

Key-words

Subnational constitutionalism, constitutional review, judicial dialogue, federalizing processes 


\section{Introductory Remarks}

This contribution tries to analyse the role of constitutional review and constitutional enforcement within subnational legal orders and their significance to the meaning of subnational constitutionalism. In doing so, it will try to look into organs and procedures and, more broadly, systems of constitutional review - in a comparative perspective ${ }^{\mathrm{I}}$.

Why should a comparative analysis of subnational constitutionalism (or subconstitutionalism, as it has also been defined ${ }^{\mathrm{II}}$ ) focus on the role of constitutional courts and constitutional review in subnational systems? There are, in my opinion, at least two good reasons for choosing such a topic.

First, the rise of constitutional review - thus meaning enforcement of constitutional provisions by the ordinary judiciary or a specialised constitutional court - has been a fundamental step in the process of legalisation of the Leviathan ${ }^{\mathrm{III}}$ :

This issue of enforcement came to prominence early on in the establishment of modern constitutions. In the older meaning of the term, "fundamental law" was understood to be a special type of law that bound "morally and politically, not legally"... The concept of fundamental law in modern constitutional regimes is associated with the emergence of the institution of judicial review ${ }^{\text {IV }}$.

A fundamental consequence of such development was the positivisation, depoliticisation and legalisation of constitutional documents, and 'the erosion of belief in the idea of the Constitution as a type of fundamental law (droit politique) different in kind to that of the ordinary law, ${ }^{\mathrm{v}}$. Furthermore, those events also affected the self-understanding of constitutional law scholarship as a distinct branch of legal scholarship ${ }^{\mathrm{VI}}$. To sum up, we have to look into the noun: is subnational constitutionalism able to shape, even thanks to the operation of constitutional review, some kind of subnational constitutional law?

Second, we have to consider the adjective: which kind of constitutional review is performed at the subnational level of federal or regional polities? According to methodological tools drawn from public choice theory, constitutions might be analysed as devices to control - and hopefully reduce - agency costs. In their survey of the defining 
traits of 'subconstitutionalism', Ginsburg and Posner hold that a proper assessment of subnational constitutionalism has to consider that agency costs are lower within subnational polities due to their being part of a broader 'superstate':

To the extent that agency costs decline when regular states become substates, the value of constitutional restrictions (in the substate) also declines. Thus, in the three areas we examine - government structure, rights, and amendment - the rules should become weaker, that is, easier to change or in other ways less likely to constrain the government. ... Because the public and political agents believe that the superstate will reduce agency costs, they feel less need to conform to constitutional rules at the substate level ${ }^{\text {IVII. }}$.

Ginsburg and Posner's assumptions mainly concern government, fundamental rights, and procedures of constitutional revision. Are they true of constitutional review as well?

These are the two main research questions which this paper will address in order to sketch a profile of subnational constitutional review. The analysis and possible answers will be organised around: (1) the existence of a relation between subnational constitutionalism and constitutional review; (2) the significance of Ginsburg and Posner's lower-stakes hypothesis to the subject of this paper; and (3) some interesting features of subnational constitutional case law.

\section{Choosing the Cases: Systems of Constitutional Review and Comparative Analysis}

When it comes to pointing out the relevant cases in this area, a preliminary distinction has to be drawn. There is a deep link between federal constitutional arrangements and the rise of constitutional review. On the one hand, German and Austro-Hungarian Staatsgerichtsbarkeit was - alongside the United States (US) model - among the leading sources of inspiration for the European model of constitutional review ${ }^{\text {VIII }}$. On the other hand, it might be worth recalling the High Court of Justice of Sicily (Alta corte di giustizia per la Regione siciliana), a peculiar example of 'arbitral' constitutional court in Italy (half of its members were appointed by the State, the other half by Sicily) which was disbanded after the establishment of the (national) Constitutional Court of Italy ${ }^{\text {IX }}$. For the purposes of this 
paper, however, I shall only consider organs or procedures aiming at enforcing subnational constitutional texts directly at the subnational level.

A rapid comparative analysis has to consider two variables: the existence of a specialised constitutional court as distinct from the ordinary judiciary, and the existence of subnational constitutional or ordinary judges. The picture is mixed ${ }^{\mathrm{x}}$. Diffuse constitutional review is the typical model in the US, Canada, Australia, or the Latin American Federations ${ }^{\mathrm{XI}}$. In turn, there are specialised constitutional courts in Germany, Austria, Belgium, Italy, and Spain. Dual judiciaries are present in the US and Australia. Austria, Belgium, Italy and Spain are all marked by federal (or central-state) monopoly over the establishment of courts. The position of Canada and Germany is somehow intermediate. On the one hand, in the former country there are both federal and provincial courts - but 'the highest level of provincial judiciary is federally appointed and paid'XII. In Germany, on the other hand, the only federal courts are the highest appellate courts, while all German Länder have their own constitutional courts. The Swiss case is quite similar to the German one, but it has limited room for constitutional review, and some Cantons have established their own constitutional courts ${ }^{\mathrm{XIII}}$. A preliminary hypothesis may be laid down: those systems where there is room for constitutional review organised at the subnational level are the ones where subnational constitutional arrangements have traditionally been thought to be a defining feature of their federal model: this is the case of the US or Germany ${ }^{\mathrm{XIV}}$. If you preliminarily take into account the original traits - and the intrinsic limits - of the local model of constitutional review, it is the case of the 'Swiss laboratory' $\mathrm{xv}$ of cantonal constitutions as well. Conversely, those systems where there are no subnational courts (e.g. Austria or Belgium) or the most senior courts are federal (e.g. Canada) have been defined by scarce scientific and political consideration of subnational constitutions ${ }^{\mathrm{XVI}}$.

The analysis will be organised as follows. It will consider: (1) enforcement of subnational constitutional law in a diffuse system of constitutional review (the US); (2) some marking aspects of a complete system of subnational constitutional courts (Germany); and (3) the problem of constitutional review in 'autonomic' legal systems where the central state holds a monopoly over it (Italy and Spain). In the end I will try to answer the two research questions that I pointed out at the beginning of this paper. 


\section{New Judicial Federalism and Majoritarian Difficulties in the US}

As Ginsburg and Posner observed, 'Americans understand subconstitutionalism as federalism, ${ }^{\text {XvII }}$, but 'the American federalism conceives of two levels of judiciaries and two levels of constitutional interpretations that are not always present in Europe ${ }^{\text {,XVIII }}$.

The US has a dual judicial system, with federal and state courts entrusted, respectively, with enforcing federal and state law. The picture, however, is not as plain as this (rather simplistic) outlook seems to show. The state courts traditionally had a weak tradition of review under state constitutional rights. Besides that, from the 1940s the incorporation of the Bill of Rights as part of the Due Process Clause of the Fourteenth Amendment to the US constitution by the Supreme Court was a fundamental turning point: 'The presence of a federal floor [i.e. those fundamental rights entrenched in the U.S. Constitution] means that the stakes are lower with state constitutions than with the Federal Constitution. The federal government bears some of the monitoring costs of state governments that would otherwise be borne by citizens ${ }^{\text {XIx }}$. In other words, that circumstance might have meant a massive, definitive endpoint of any 'constitutional' ambitions of state courts.

In 1977, however, a well-known article by Justice Brennan pleaded for the contrary, symbolically paving the way for the 'New Judicial Federalism'. The framework of Brennan's insight was the unprecedented expansion of the regulatory scope of federal law from the Great Depression to the 1970s, which should not have been thought to relieve state courts from their duties of constitutional review, even with regard to those state rights otherwise unavailable under the US Constitution: 'The legal revolution which has brought federal law to the fore must not be allowed to inhibit the independent protective force of state law ${ }^{\mathrm{Xx}}$. In fact, that federalising trend also had in itself some signs of its decline, with the US Supreme Court eventually 'adopting the premise that state courts can be trusted to safeguard individual rights ${ }^{\mathrm{xxI}}$. On the one hand, the complex trend known as New Judicial Federalism was to be mainly a reaction to the more minimalist approach of the Burger and Rehnquist Courts towards fundamental rights issues. On the other hand, this trend was favoured - and, to a certain extent, made possible - by a doctrine of self-restraint of the US Supreme Court itself, which affirmed that it would not have reviewed state court decisions resting upon an adequate state ground ${ }^{\mathrm{XXII}}$. 
That period has been labelled as a 'golden age' of state constitutional law and the starting point of renewed scientific interest in the topic ${ }^{\mathrm{XXIII}}$. One of the chief assumptions of the trend was Justice Brennan's claim that 'one of the strengths of our federal system is that it provides a double source of protection for the rights of our citizens ${ }^{\text {,Xxiv }}$.

As has been noted, New Judicial Federalism was prompted by the more activist attitude of the Warren Court - whilst prior contributions of the state courts to the development of the protection of fundamental rights were negligible: 'state supreme courts did not develop a body of civil liberties law prior to the 1930s'. Thus, according to Tarr, the New Judicial Federalism 'represents not a return to the past but 'an unprecedented exercise of state judicial power ${ }^{\mathrm{Xxv}}$. The activism of the Warren Court might not have been so detrimental to federalism as its critics pretended: 'the protection of civil liberties should not be viewed as a zero-sum game, in which increased activity by one judiciary necessitates decreased activity by the other. Rather, the relationship between federal and state judiciaries involves a sharing of responsibility and a process of mutual learning, ${ }^{\mathrm{XxVI}}$. This explanation may be interpreted as not perfectly coinciding with Ginsburg and Posner's outlook; indeed, a strengthened constitutional review in the 'superstate', as they call it, might be the most important factor for a system of state courts to initiate an intensive work of effective construction and enforcement of their own constitutional laws. Other commentators, in turn, have also tried to argue that the New Judicial Federalism is not really novel but rather a 'rediscovery' of state constitutions and state declarations of rights ${ }^{\text {XxvII }}$.

Even if the actual achievements of New Judicial Federalism are controversial - most of all for its actual dimensions and its real influence over the evolution of the US legal system as a whole ${ }^{\mathrm{xxVIII}}$ - this trend seems to have been crucial for a radical re-evaluation of state constitutional law.

Some other data, however, impose a more nuanced analysis of those developments in the US. These affect, first, the intrinsic characters of state constitutional law as entrenched in state constitutions and, second, the position of the judiciary within state political systems and political processes.

Due to reasons concerning state constitutionalism in the US - which have been carefully scrutinised by Williams ${ }^{\text {xxIx }}$ - state rights are usually more weakly entrenched than national rights. For the purposes of this paper, this circumstance does entail that legislatures and voters within the states are much more willing to reverse decisions by the 
state courts by means of constitutional revision, modifying of even suppressing provisions entrenched in their fundamental charters. Another possible occurrence is the recall of state judges, which perfectly fits weaker separation of powers and an inclination towards direct democracy or populism, which are also supposed to be typical of state constitutionalism $^{\mathrm{xxx}}$.

Some other data, however, might contradict or, at least, relativise the picture. As I have just recalled, 'in one sense, these court-constraining amendments have been an enduring feature of the state constitutional tradition, ${ }^{\mathrm{Xxx}}$, and since the 1970s they have been passed most of the time in order to reverse state court decisions concerning civil rights and liberties $^{\text {XXXII }}$. A significant point is that the recent wave of court-constraining - or to be more correct, court-overturning amendments - has been severely criticised by scholars, who think 'that they are improper insofar as they take matters that should be resolved by the judiciary and place them in the political process, ${ }^{\text {XxxIII }}$. This kind of criticism is obviously related to the broader debates on the virtues of political constitutionalism or the source of legitimacy of judicial 'activism, ${ }^{\text {xxxiv }}$; however, it also suggests that a more deeply rooted consciousness of the practical relevance of state constitutional law has been spreading.

These final remarks might even suggest that New Judicial Federalism and activism of state courts might slowly but inexorably challenge many commonplaces in the perception of state constitutional law. Briefly, they might not only have attracted scholarly and public attention towards the contents of state constitutions and their own original bills of rights, they might also have induced a change in the status of state constitutional law.

\section{Constitutional Review in the German Länder}

As mentioned before, the German judiciary is traditionally characterised by the presence of a number of specialised branches, among which is a court specifically entrusted with constitutional review (Verfassungsgerichtsbarkeit). Accordingly, fifteen out of sixteen Länder in Germany decided to establish a constitutional court of their own. The only exception was Schleswig-Holstein which, according to Article 99 of the German Basic Law, handed over 
to the Federal Constitutional Court the power to decide over 'its' constitutional disputes. In 2008, however, a Constitutional Court of Schleswig-Holstein was established ${ }^{\mathrm{xxx}}$.

According to a well-established view, three 'waves' of constitution-making are recognisable throughout the Länder of the Federal Republic of Germany: the first phase lasted from 1945 to 1949, the second phase lasted from 1949 to 1990, and the third and current phase started in 1990, with the enactment of the Basic Law and the reunification seen as major turning points ${ }^{\mathrm{Xxx}}$. This chronological classification is mainly focused on the contents of the constitutions of the Länder, most of all on the provisions concerning constitutional principles, fundamental rights, and 'goals of state action' (Staatsziele). It is of the greatest interest to draw a parallel between that story of constitution-making and the establishment of constitutional review in the German Länder from the mid-1940s onwards. Seven Landesverfassungsgerichte were established between the end of the Second World War and 1949 in Bavaria (1947), Hesse (1947), Bremen (1949), Rhineland-Palatinate (1949), Baden, Württemberg-Baden, and Württemberg-Hohenzollern (the three latter Länder were later dissolved into Baden-Württemberg). This first phase was quite diverse in cultural influences, which came both from the old Germanic traditions of Staatsgerichtsbarkeit and Verfassungsgerichtsbarkeit, and pressures from the Western occupying powers. Constituent assemblies in the Länder set out a rich array of procedures of constitutional review, whose best examples might be find out in Bavaria. After 1949 - the Bundesverfassungsgerichtsgesetz dates back to 1951, and the Federal Constitutional Court started its activity in the same year - five other Land constitutional courts were established in North Rhine-Westphalia (1952), Hamburg (1954), Baden-Württemberg (1955), Lower Saxony (1955), and Saarland (1958). In some cases - for example, Lower Saxony - the Land ordinary law establishing the constitutional court just deferred to the correspondent federal law. Most interestingly, none of these courts had full competence (if any) over individual complaints (Verfassungsbeschwerden). This might look quite striking in those Länder whose constitution contains a bill of rights (indeed, it was not [yet] the case of Hamburg and Lower Saxony). Seven constitutional courts have been established after the reunification in Berlin (1990), Brandenburg (1993), Saxony (1993), Saxony-Anhalt (1993), Mecklenburg-Western Pomerania (1994), Thuringia (1994), and Schleswig-Holstein (2008). The enriched competences of those courts - inclusive of individual complaints - seem to show a new interest 'to promote the self-understanding of the Länder over their constitutional law and 
the consciousness of their statehood by means of autonomous and binding interpretation of the Constitution of the Land ${ }^{\text {XXxvII. }}$

This chronological insight seems to confirm that constitutional review is a crucial element in understanding the significance of a subnational constitutional arrangement. The post-1990 phase of constitutional fervour in the Eastern Länder - and, subsequently, in the West as well - could not be limited to constitution-making and the updating of the fundamental rights entrenched in the Basic Law. Constitutional review was an obvious component of that trend.

Nevertheless, some elements seem to confirm Ginsburg and Posner's claim on the lesser significance of stakes at the subnational level, too. First of all, the length of the term of constitutional judges and their possibility of being re-elected should be considered. According to comparative scholarship on constitutional review, those members of constitutional courts who are elected by legislatures or appointed by executive officeholders should normally stay in office during good tenure (as happens in the US) or for a term whose length largely exceeds the duration of the legislature. Re-election is normally excluded in order to avoid possible collusion between the appointees and political officeholders. In Germany, for instance, the judges of the Federal Constitutional Court, the Bundesverfassungsgericht, are elected for twelve years (unless they attain the mandatory age of retirement of sixty-eight before) and cannot be re-elected for another term ${ }^{\text {XxxvIII }}$. A twothirds majority of the members of the Bundesrat or the Election Committee of the Bundestag is required ${ }^{\mathrm{XxxIx}}$. As for personal requirements, appointees have to be eligible to become ordinary judges (so-called Befähigung zum Richteramt) ${ }^{\mathrm{XL}}$. A strict regime of incompatibilities is laid down by the law ${ }^{\mathrm{XLI}}$.

If you consider the situation in the Länder, a trend towards homogeneity - or a generalised mechanic transposition of the provisions of the Law establishing the Federal Constitutional Court - can hardly be recognised.

All the elected members of the Constitutional Court of Bremen, some of the members of the Constitutional Court of Bavaria and six members of the Constitutional Court of Hesse are elected for five years, i.e. the same as the term of the legislature of the Land $d^{\mathrm{XLII}}$. Judges of the Constitutional Courts of Hamburg, Rhineland-Palatinate, Lower Saxony and Saxony-Anhalt are entitled to re-election for another term. Judges of the Constitutional Courts of Baden-Württemberg, Saxony, Bavaria, Hessen, North Rhine-Westphalia, 
Thuringia and Bremen can be re-elected without any time restrictions ${ }^{\text {XLIII }}$. Re-election, instead, is not allowed in Berlin, Brandenburg, and Mecklenburg-Western Pomerania. A plurality of members of the Land legislature is enough to elect constitutional judges in Baden-Württemberg, Bavaria, Bremen, Hamburg, Hesse, and North Rhine-Westphalia ${ }^{\text {XLIV }}$. This circumstance can be duly assessed taking into account that the political systems of subnational polities are more likely to be characterised by a dominant party than their national counterparts - and many German Länder are not an exception ${ }^{\mathrm{XLV}}$.

Finally, members of constitutional courts in the Länder mostly fulfil their duties on a volunteer basis (ehrenamtlich) or as a secondary task (nebenamtlich): thus, when necessary, they can be replaced by substitutes ${ }^{\mathrm{XLVI}}$.

As for procedures, there are both similarities and differences with what the Bundesverfassungsgerichtsgesetz, prescribes for the Federal Constitutional Court. Perhaps the most original procedure to go before a Land constitutional court - and which has no equivalent at the federal level - is Bavarian popular action (Popularklage), whereby everybody may challenge the constitutional legitimacy of a piece of Land legislation in a typically abstract review, without having to prove a violation of his or her fundamental rights ${ }^{\mathrm{XLVII}}$.

Individual complaints - one of the procedural tools for which the Germanic model of constitutional review is best-known - are admitted under different conditions in just ten Länder. In many cases, Landesverfassungsgerichte are just entitled to review Land legislative or regulatory acts, and not judicial decisions - even in order to avoid conflicts with federal appellate courts (e.g. the Federal Court of Justice or the Federal Administrative Court). In some Länder, individual complaints can be initiated before their constitutional courts only if a parallel individual complaint before the Bundesverfassungsgericht has not been or is not being initiated $^{\mathrm{XLVIII}}$. This is a mostly subsidiary form of constitutional review, which has been revitalised since the 1990s even in order to reduce the workload of the Bundesverfassungsgericht, thus setting up the conditions for a 'doubled protections of rights ${ }^{\text {XLIx }}$. This has been the outcome of a proactive attitude of some Landesverfassungsgerichte, a skillful work of dialogue of the Federal Constitutional Court, and a passionate debate among constitutional scholars ${ }^{\mathrm{L}}$. A favourable framework for such developments was provided by the 'third wave' of constitution-making starting in the Eastern Länder in the aftermath of the reunification ${ }^{\text {LI }}$. 
The great issue at stake was whether a Land constitutional court could review under the provisions of the Land constitution a judicial decision of a Land court in which the latter had applied federal legislative law. The first plausible (and positive) answer came from the newly established Constitutional Court of Berlin in the so-called Honecker case:

'the present individual complaint is not less admissible because the challenged judgements have applied provisions of the Criminal Procedure Ordnance, i.e. federal law. The crucial point is that those are acts of the Land Berlin (Article 49(1) of the Land law on the Constitutional Court). The fundamental rights entrenched in the Constitution of Berlin are binding for the judiciary of the Land Berlin (Article 23(1) of the Constitution of Berlin) and may be taken into account - compatibly with Articles $142^{L I I}$ and 31 of the Basic Law - if it [i.e. the Land courts] applies federal law ${ }^{\text {LIII }}$.

On the other side, scholars noticed 'an evident trend' in the case law of the Federal Constitutional Court aiming at strengthening its counterparts in the Länder, in order also to reduce its workload ${ }^{\mathrm{LIV}}$. Dealing with a reference from the Constitutional Court of Saxony, the Bundesverfassungsgericht held that the Basic Law does not prevent a Land Constitutional Court from reviewing the application of federal procedure law by a court in the Land under fundamental rights and right-equivalent guarantees of the Land constitution having the same content as the corresponding right in the Basic $\mathrm{Law}^{\mathrm{LV}}$. This position of the Bundesverfassungsgericht implicitly approved the claims which had been made by some although not all - Landesverfassungsgerichte in the preceding years. This has led some commentators to claim that 'to speak today of an exclusive or primary responsibility of the Federation for the enforcement of constitutional law appears dubious ${ }^{\mathrm{LVI}}$.

Finally, the case law of constitutional courts in the Länder deserves a mention. It has mostly been characterised by a significant dialogue - in the broadest, least technical sense among Landesverfassungsgerichte and with the Bundesverfassungsgericht. Two examples are sufficient: the legitimacy of the $5 \%$-threshold, which is a landmark in German election systems at all institutional levels, has been (successfully challenged) before some Landesverfassungsgerichte with regard to its application in municipal elections ${ }^{\text {LVII }}$ - before the Federal Constitutional Court decided to declare its constitutional illegitimacy in municipal elections or in the election of German Members of the European Parliament ${ }^{\mathrm{LVIII}}$. Another interesting example does concern the recent balanced-budget amendments which cast 
duties on both the Bund and the Länder: in 2011, the Constitutional Court of North RhineWestphalia recognised the budget of the Land as unconstitutional for violating the new rules on public indebtment ${ }^{\text {LIX }}$. Without trying to draw general conclusions from insulated cases, what seems to emerge is that Landesverfassungsgerichte quite often succeed in anticipating federal judicial trends.

\section{Dilemmas of the 'Regional State'}

Traditionally, European constitutional scholarship tends to cast a distinction between federal and regional legal systems. Apart from Belgium, those previously unitary states in Continental Europe which conferred some degree of institutional and legislative autonomy to their territorial units in the 20th century were labelled as 'regional states': this is the case of the Spanish Third Republic or the Italian Republic ${ }^{\mathrm{LX}}$.

Even if the distinction between federalism and regionalism is fading among constitutional lawyers and political scientists ${ }^{\mathrm{LXI}}$, its theoretical foundations are not without effect on present-day assumptions concerning many legal aspects of regional autonomy in both Italy and Spain ${ }^{\text {LXII }}$. As the Spanish Constitutional Court has recently stated,

it is self-evident ... that one of the defining traits of the autonomic State, insofar as it is different from the federal State, is that its functional and organic pluralism does not affect the judiciary at all. In the autonomic State, the diversification of the legal system, resulting in more autonomous normative systems, does not take place at the constitutional level - entailing the existence of more constitutions (federal and subnational). Conversely, it only starts at the level of ordinary laws, in presence of one national constitution $^{\text {LXIII }}$.

Thus even if the practical operation of the Spanish federalising process has gone well beyond a mere autonomic frame, the traditional scholarly distinction between federal systems and autonomous (or regional) ones is still relevant to the self-understanding of the system.

For the purposes of this paper, in particular, it is clear that: (1) (central-state) constitutional courts are quite hostile towards any recognition whatsoever of a subnational 
constitutional law ${ }^{\mathrm{LXIV}}$; and (2) there can be only one interpreter of the Constitution, i.e. the (national) constitutional court ${ }^{\mathrm{LXV}}$.

Due to different reasons, both countries have undergone a process of in-depth revision of subnational fundamental charters (Statuti of Italian ordinary regions, Estatutos of Spanish autonomous communities) in the last decade. After approving new, more ambitious regional charters, a concern arose: how to ensure the compatibility of legislative and administrative activity of a Region with the provisions of its charter - in other words, how to take this piece of fundamental law seriously. In Italy, a law may be declared unconstitutional under Article 123 of the Constitution if it violates a regional Statuto. Because, among other reasons, of the procedural difficulty of reviewing legislation under the provisions entrenched in the regional Statuti, however, the Italian Constitutional Court has quite rarely used those provisions to review the legitimacy of (regional) ordinary legislation $^{\mathrm{LXVI}}$.

Furthermore, another major concern is how to build up a 'culture' of legislation and administration at the subnational level in countries that have traditionally had a very centralised organisation. At the national level, this function has traditionally been performed by a very prestigious consultative organ, called the Council of State in both countries.

In Spain, for instance, organic law no. 3/1980 on the functions of the Consejo de Estado allows it to 'give advice' to the autonomous communities as well. Subsequently the Spanish Constitutional Court made it clear that autonomous communities are empowered to establish consultative bodies of their own, 'equivalent to the Consejo de Estado' in organisational and functional terms ${ }^{\text {LXVII }}$. In Italy, the problem might have been even more acute because the Consiglio di Stato has traditionally been more interested in developing its judicial case law than its consultative functions - being very careful, meanwhile, of preventing the rise of decentralised consultative organs ${ }^{\mathrm{LXVIII}}$.

Both Spanish autonomous communities (since the 1990s) and Italian regions (since the 2000s) have established consultative bodies entrusted with assessing a priori the compatibility of regional legislative and administrative business with, respectively, Estatutos or Statuti ${ }^{\mathrm{LXIX}}$. To mention just an example, the Consulta di garanzia statutaria of EmiliaRomagna is entrusted with: (1) reviewing those events that have provoked a precocious dissolution of the legislature; (2) expressing opinions on popular legislative propositions or 
regional referendums; (3) expressing opinions over the compatibility with the Statuto of regional laws and regulations; and (4) solving possible conflicts among regional organs.

Those organs share some features with both the legislative and the judiciary ${ }^{\text {Lxx }}$. In Italy their functions mainly concern the methods of regional legislation and its compliance with procedural standards laid down in the regional charters. This appears to be very interesting in an age marked by the perception of an irresistible decline of representative legislatures and the legislative function ${ }^{\text {LXXI }}$. They embody a sort of 'public' consultative function which faces a radical change in legislation: 'legislative activity has radically changed in the last few decades: it has become extraordinarily more complex than has happened before, much more limited and constrained ${ }^{\text {LXXII }}$. Besides this, however, those consultative bodies should also play a role of protection of minorities and, most interestingly, of local government authorities, which have generally no standing before national constitutional courts. Furthermore, they are supposed to act in an institutional framework characterised - as it happens in Italy - by the presence of a strong executive and a legislature which is always dominated, thanks to the peculiar features of election systems, by the regional president's coalition $^{\text {LXXIII }}$. This is why structural aspects of consultative bodies are carefully laid down, so as to allow political minorities to have a say in the designation of their components.

A good example of the possibilities and the limitations characterising this trend comes from the much-discussed judgement of the Spanish Constitutional Court on the ambitious Estatut of the autonomous community of Catalonia ${ }^{\text {LxxIV }}$. In particular, the Estatut changed the Consejo Consultivo into a Consell de Garanties Estatutàries (Council for Statutory Guarantees), 'the institution of the Generalitat that ensures that the regulations of the Generalitat comply with this Estatut and the Constitution, ${ }^{\text {,Xxx }}$. However, in the light of the aforementioned considerations on the differences between federations and autonomic states, the deliberations of the Consell de Garanties Estatutàries (Council for Statutory Guarantees) cannot bind the legislature - the Consell cannot aim at becoming a sort of constitutional court of Catalonia: 'there are substantial and evident conceptual differences between the ... functions typical of consultative bodies and judicial functions which are exclusively exercised by courts, in general, and this Court, in particular, as far as its condition of supreme judicial interpreter of the Constitution is concerned ${ }^{\text {LXXVI }}$. Since the Spanish legal system has just one Constitution, there can be only one Constitutional Court. Consequently, the Court declared the illegitimacy of a provision of the Estatut according to 
which 'the judgments of the Consell de Garanties Estatutàries in relation to Government bills and Members' bills in Parliaments that develop or affect the rights recognized in this Estatut, are binding in nature ${ }^{\text {,LXVII }}$.

\section{A Possible Conclusion}

In my opinion, the comparative analysis that I have tried to sketch in this paper does lend itself to some conclusions which do not necessarily fit into a harmonious and coherent picture. Still, they might provide a faithful representation of the 'spirit' of subnational constitutionalism in the legal systems which I have considered.

First, there is a persuasive link between lively subnational constitutional arrangements and the existence of some form of constitutional review at the subnational level. Furthermore, revitalisations of subnational constitutional review tend to attract attention towards subnational constitutional law. This is certainly true of the US. The German case, in turn, might suggest a slightly different explanation: as seen before, efficiency-driven concerns - which an American observer would identify as the defining feature of European federalisms $^{\text {LXXVIII }}$ - may have had a crucial role in strengthening the role of Landesverfassungsgerichte ${ }^{\text {LXXIX }}$. The recent developments in Italian regions and Spanish autonomous communities prove how subnational communities are conscious of the necessity of having an independent body overseeing the compliance of regional legislative and administrative business with their fundamental charters, thus supporting their function of fundamental law or, in other words, 'basic institutional norm' of a subnational polity $^{\text {Lxxx }}$.

Second, constitutional review is a good field to check the sustainability of Ginsburg and Posner's hypothesis. Here again, subnational constitutionalism tends to be understood as 'subconstitutionalism' - that is, a kind of constitutionalism whose operation is largely dependent from its inclusion in a larger, comprehensive constitutional order. Thus both organisational and functional aspects (see the German case), on the one side, and the position of constitutional review within the broader subnational polity (think of courtconstraining amendments in the US), on the other, show that constitutional law - as a kind of fundamental law - tends to be taken less seriously at the subnational level. Indeed, the 
position of constitutional courts - or ordinary courts entrusted with constitutional review within subnational institutional systems is often dependent on how the national constitutional court decides to interpret their mutual relations and their respective roles in the enforcement of constitutional law (see the attitudes of the US Supreme Court and the Bundesverfassungsgericht in sections 3 and 4).

Third, lower constitutional stakes - whose existence cannot be denied - are also an incentive to make experimentations. Constitutional review probably offers a good example of subnational constitutional arrangements as a specification of the view of federalism as an organisational form which allows and actually (hopefully) encourages institutional experimentation. The most famous exposition of this view is Justice Louis D. Brandeis' dissenting opinion in New State Ice Co. v. Liebmann: 'It is one of the happy incidents of the federal system that a single courageous state may, if its citizens choose, serve as a laboratory; and try novel social and economic experiments without risk to the rest of the country $^{\text {,LXXXI }}$. This conception is deeply rooted in the American understanding of state constitutionalism as an intrinsic element of federalism, as the Supreme Court more clearly argued in the Lopez case: 'In this circumstance, the theory and utility of our federalism are revealed, for the States may perform their role of laboratories for experimentation to devise various solutions, ${ }^{\text {LXXXII }}$.

I will just recall three examples: as different as they are, they offer a convincing demonstration of this assumption and possibly allow provision of an even more nuanced conclusive picture. The first one is New Judicial Federalism in the US: as said before, some commentators have seen the rise of enforcement of state fundamental rights by state courts as a development prompted by the activist attitude of the Warren Court until the late 1960s; this, however, might also suggest that a stronger role of constitutional review at the federal level (i.e. in the 'superstate') does not necessarily entail a more relaxed attitude on the side of state courts. The second example is popular action in the Freistaat Bavaria: the introduction of a procedural tool which is quite rare in most legal systems has allowed the Constitutional Court of Bavaria to elaborate the richest and most significant case law among the German Land constitutional courts.

Third, I think it is important to point out again the possibility of regional consultative bodies of reviewing regional legislative procedures in Italy, where the national Constitutional Court has consistently held that the internal proceedings of the Parliament 
are more often outside the scope of its reviewing activity ${ }^{\mathrm{LXXXIII}}$. In my opinion, this trend might be properly evaluated if a comparison is made with the willingness of German Land constitutional courts to review budgetary legislation under the provisions of the Finanzverfassung after the 'Second Reform of Federalism' in 2009, as has happened in North Rhine-Westphalia. These are meaningful innovations because of the traditional deference of the courts towards political office-holders in what has long been seen as the most vital core of representative democracy - financial decision-making. As has been held, those changes have been possible at the subnational level 'because it may be less tightly committed to the rhetoric of sovereignty ${ }^{\text {LXXXIV }}$.

These are all important demonstrations of how the subnational constitutional space may act as a laboratory not only with regard to higher levels of protection of fundamental rights but also to a more transparent and participative political process. If this assumption is correct - as I think it is -well-known narratives of subnational constitutional systems being pervaded by majoritarian traits and lesser guarantees for political minorities could be partially reconsidered. In other words, 'lower stakes' may also mean lesser deference towards the most jealously preserved domaines réservés of the legislative and the executive.

\footnotetext{
* Ph.D. candidate in Constitutional Law, Sant'Anna School of Advanced Studies, Pisa (Italy). Email address: giacomo.delledonne@gmail.com. I would like to thank Robert F. Williams, Giuseppe Martinico and the anonymous reviewers for their precious suggestions and comments. Usual disclaimers apply.

I As for general comparative analyses of constitutional review, see Favoreu 1996 and Pizzorusso 2007.

II Ginsburg and Posner 2010.

III This trend, however, has also been criticised: think e.g. of 'constitutional review positivism' (Verfassungsgerichtspositivismus) and its influence on constitutional law scholarship (Cassese 2010: 396-397).

IV Loughlin 2010: 288.

v Loughlin 2010: 296.

VI See Pizzorusso 2006, Neuborne 2007 and Heuschling 2008 (concerning the French tradition of constitutional law scholarship and the rise of the école d'Aix-en-Provence after the establishment of the Conseil constitutionne). The prior situation - well exemplified by Vittorio Emanuele Orlando, one of the leading representatives of traditional public law scholarship in continental Europe - is plainly illustrated in Cassese 2011.

VII Ginsburg and Posner 2010: 1596

VIII See Pierandrei 1962: 899; Pizzorusso 1981: $21 \mathrm{ff}$.

IX See Constitutional Court of Italy, sentenze no. 38/1957 and no. 6/1970: 'all norms relating to the High Court are incompatible with the Constitution. Indeed, in a unitary state - even though its structure is based on extensive territorial pluralism (Article 5 of the Constitution) - the principle of a unitary judiciary cannot be
} 
limited' (both available at http://www.cortecostituzionale.it). According to Article 25 of the regional charter (Statuto) of Sicily of 1946, the high court was basically entrusted with reviewing the compatibility of state and regional laws with the Statuto and the Italian Constitution, 'for the purposes of their validity within the Region'. Neither am I interested in the review of subnational constitutional texts by national constitutional courts (see Fossas Espadaler 2011: 39-44).

$\mathrm{x}$ See also comprehensive comparative data collected by Dr. Arne Mavčič, available at http://www.concourts.net.

XI As for the Argentine case, see Hernández 2010.

XII Russell 2009: 267.

XIII Martinico 2011: E 68. Meanwhile, Cantons Basel, Jura and Nidwalden have established their own constitutional courts (the administrative court of Canton Basel is a constitutional court, too).

XIV See Elazar 1999.

xv Häberle 2008: 278.

XVI See e.g. Tarr 2009: 768 and Popelier 2012.

xVII Ginsburg and Posner 2010: 1588.

XVIII Delledonne and Martinico 2011: 2.

XIX Ginsburg and Posner 2010: 1605. See also Brennan 1977: 493-495.

xx Brennan 1977: 491. A detailed account is provided by Williams 2009: 113-134.

Xxi Brennan 1977: 502-503.

xxII US Supreme Court, Michigan v. Long, 463 US 1032-1402 (1983). See also Murdock v. City of Memphis (87 US (20 Wall.) 590 (1875)); more indications in Fercot 2008: 318.

XXIII Williams 1998: 764.

xxIV Brennan 1977: 503 (emphasis added).

xxv Tarr 1994: 69.

xxvi Tarr 1994: 73.

xxvII See Abrahamson 1985.

xxvIII See again Tarr 1994: 73-77.

xxix See Williams 2009.

xxx See Ginsburg and Posner 2010: 1606; Williams 2009: 32-33.

xxxi Dinan 2007: 986.

xxxil See Dinan 2007: 988-989.

xxxiII Dinan 2007: 1020. The author also quotes some occasions on which state courts invoked procedural requirements 'to block court-constraining amendments from taking effect'. See e.g. Supreme Court of California, Strauss v. Horton, 46 Cal. 4th 364 (2009).

xxxiv See Komesar 1988 and Pierdominici 2011.

xxxv Article 44(1) of the Constitution of Schleswig-Holstein underwent an ad hoc revision in 2006.

xxxvi Maurer 2007: 155 ff.

XxxvII See Starck 2008: 321.

xxxvIII See Article 4 of the Law on the Federal Constitutional Court (Bundesverfassungsgerichtsgesets).

xxxix See Article 6 of the Bundesverfassungsgerichtsgeset:

XL See Article 3 of the Bundesverfassungsgerichtsgeset:

XLI Article 3(3)(4) of the Bundesverfassungsgerichtsgeset\%.

XLII See Article 139(3) of the Constitution of Bremen, Article 4(2) of the Bavarian Law on the Constitutional Court of the Land (VfGHG, available at http://by.juris.de: 'The other members and their substitutes are elected by the new Landtag after ist inaugural session according to the principles of proportional representation'), and Article 130(2) of the Constitution of Hesse.

xLIII See Article 4(3) of the Bavarian VfGHG, Article 130(3) of the Constitution of Hesse, and Article 139(3) of the Constitution of Bremen.

XLIV See Article 2 of the Baden-Württemberg Law on the Constitutional Court of the Land (StGHG), Article 4 of the Bavarian VfGHG, Article 139(2) of the Constitution of Bremen, Article 4 of the Hamburg Law on the Constitutional Court of the Land (VerfGG), and Article 76(1) of the Constitution of North RhineWestphalia.

XLV Think, for example, of Bavaria, where the Christian Social Union held a majority of seats in the Landtag from 1962 until 2008; or Bremen, where the German Social Democratic Party held a majority from 1971 to 1991. 
XLVI See comprehensive comparative analysis by Starck 2008: 329-332. See also Starck and Stern 1983. XLVII See Article 98(4) of the Bavarian Constitution and Article 55 of the Bavarian VfGHG: 'Everybody is entitled to challenge the constitutional legitimacy of a legal provision of law of the Land Bavaria before the Constitutional Court by means of complaint. He or she has to allege that a fundamental right entrenched in the Constitution is illegitimately limited'.

XLVIII See Starck 2008: 341-343.

xuIx See Tietje 1999.

L See Starck 1993, Rozek 1994, Zierlein 1995.

LI See Häberle 1993.

LII 'Notwithstanding Article 31, provisions of Land constitutions shall also remain in force insofar as they guarantee basic rights in conformity with Articles 1 to 18 of this Basic Law'.

LIII Verfassungsgerichtshof des Landes Berlin, decision of 23 December 1992 (VerfGH 38/92), available in Entscheidungen der Verfassungsgerichte der Länder Berlin, Brandenburg, Mecklenburg-Vorpommern, Sachsen-Anhalt, Thüringen, de Gruyter, Berlin and New York 1996: 44-56, 51.

LIV Tietje 1999.

LV Bundesverfassungsgericht, decision of the 2nd Senate of 15 October 1997 (in Neue Juristische Wochenschrift, 1998: 1296 ff.).

LVI Tietje 1999: 301-302.

LVII Verfassungsgerichtshof für das Land Nordrhein-Westfalen, judgement of 6 July 1999 (VerfGH NRW OVGE 47, 304); Thüringer Verfassungsgerichtshof, judgement of 11 April 2008.

LVIII Bundesverfassungsgericht, judgements of 13 February 2008 (BVerfG, 2BvK 1/07) and 9 November 2011 (BVerfG, 2 BvC 4/10).

LIX Verfassungsgerichtshof für das Land Nordrhein-Westfalen, judgements no. 19/2011 and no. 20/2011, both available at http://www.vgh.nrw.de/entscheidungen/index.php.

LX In Italy, this scholarly distinction dates back to Gaspare Ambrosini, who extensively studies the Spanish Constitution of 1931, was largely responsible for the drafting of the section of the Constitution of 1948 devoted to regional and local government and went on to preside over the Italian constitutional court from 1962 to 1967 (see Ambrosini 1944).

LXI See e.g. Baldi 2003: XI ff.

LXII See e.g. Italian Constitutional Court, sentenza no. 365/2007, which traces a rigid distinction between sovereignty (in federal states) and autonomy (in regional states) of subnational units.

LXIII Spanish Constitutional Court, sentencia no. 31/2010, par. 42. See also Falcon 2010.

LXIV See Delledonne and Martinico 2011: 6-15.

LXV See Italian Constitutional Court, sentenza no. 6/1970 (supra, at x), and Spanish Constitutional Court, sentencia no. 31/2010.

LXVI See Romboli 2005: 284. There are, however, some exceptions. See e.g. the sentenze no. 188/2011, no. 68/2010, no. 119/2006, no. 993/1988, and no. 48/1983 (all available at http://www.cortecostituzionale.it). See also Spanish Constitutional Court, sentencia no. 247/2007 (on the legitimacy of the Estatuto of the Valencia Community), where the Court has stated that the relation between the Constitution and the Estatutos de autonomia of the autonomous communities is one of subordination as well as mutual integration, since the Estatutos are also part of the bloque de constitucionalidad which the Court uses to assess the legitimacy of a norm. Even in Spain, however, the Court has hardly ever used the Estatutos to review the legitimacy of legislation. LXVII Spanish Constitutional Court, judgement no. 204/1992 (quoted by Garrido Moyol 2011: 640).

LXVIII See Lupo 2011: 628.

LXIX As for Spain, Article 129 of the Estatuto of Andalusia (Consejo Consultivo), Article 58 of the Estatuto of Aragon (Consejo Consultivo), Article 76 of the Estatut of the Balearic Islands (Consejo Consultivo), the autonomic law no. 9/2004 of the Basque Country (Comision Juridica Asesora de Euskadi), Article 44 of the Estatuto of Canary Islands (Consejo Consultivo), Article 38 of the Estatuto of Cantabria (Consejo Jurídico Consultivo), Article 13 of the Estatuto of Castile-La Mancha (Consejo Consultivo), Article 33 of the Estatuto of Castile and León (Consejo Consultivo), Article 76 of the Estatut of Catalonia (Consell de Garanties Estatutàries), Article 45 of the Estatuto of Extremadura (Consejo Consultivo), the autonomic law no. 9/1995 of Galicia (Consejo Consultivo), Article 42 of the Estatuto of La Rioja (Consejo Consultivo), the autonomic law no. 6/2007 of the Madrid Community (Consejo Consultivo), the autonomic law no. 2/1997 of the Murcia Region (Consejo Juridico), the foral law no. 8/1999 of Navarra (Consejo de Navarra), Article 35 quater of the Estatuto of the Principality of Asturias (Consejo Consultivo), and Article 43 of the Estatut of the Valencia Community (Consell Juridic Consultiu). See also Garrido Moyol 
2011, Tornos Mas 2010, Vintró Castells 2010, Carillo 2008. As for Italy, see the Statuti of Abruzzo (Articles 79 and 80, establishing a Collegio regionale per le garanæie statutarie), Calabria (Article 57, establishing a Consulta statutaria), Campania (Article 57, establishing a Consulta di garanæia statutaria), Emilia-Romagna (Article 69, establishing a Consulta di garanzia statutaria, implemented by regional law no. 23/2007), Latium (Article 68, Comitato di garanzia statutaria), Liguria (Articles 74 and 75, establishing a Consulta statutaria, implemented by regional law no. 19/2006), Lombardy (Articles 59 and 60, establishing a Commissione garante dello Statuto), Molise (Article 69, establishing a Consulta statutaria), Piedmont (Articles 91 and 92, establishing a Commissione di garanzia), Apulia (Articles 47, 48 and 49, establishing a Consiglio statutario regionale), Tuscany (Article 57, establishing a Collegio di garanzia, implemented by regional law no. 34/2008), Umbria (Articles 81 and 82, Commissione di garanzia statutaria), and the draft Statuto of Veneto (Article 62, establishing a Commissione di garanzia statutaria). See also Lupo 2011, Piperata 2011, Napoli 2008, and Cardone 2006.

LXX They have even been likened to a sort of 'technocratic' second chamber within the regional legislature alongside the regional council (Lupo 2011: 634-635).

LXXI For a recent analysis of the Italian situation see Zaccaria 2011.

LXxII Lupo 2011: 628.

LXXIII See Fasone 2012.

LXXIV See Delledonne 2011.

LXxv Article 76(1) of the Estatut of Catalonia.

LXXVI Spanish Constitutional Court, sentencia no. 31/2010, par. 32.

LXXVII Article 76(4) of the Estatut of Catalonia prior to sentencia no. 31/2010 (emphasis added).

LXXVIII See Gardner 2008.

LXXIX German scholars, however, have felt it necessary to specify that the reduction of the workload of the federal constitutional court 'is to be applauded for constitutional law reasons' (Tietje 1999: 283).

LXxx Spanish Constitutional Court, sentencia no. 31/2010, par. 4.

LXXXI US Supreme Court, New State Ice Co. v. Liebmann, 285 US 262, 311 (1932).

LXXXII US Supreme Court, United States v. Lopez, US (1995), 14. See also San Antonio School District v. Rodriguez, 411 US 1, 50 (1973).

LXxxiII See Italian Constitutional Court, sentenza no. 6/1959.

LXXXIV Lupo 2011: 629.

\section{References}

- Abrahamson Shirley S., 1985, 'Criminal Law and State Constitutions: The Emergence of State Constitutional Law', in Texas Law Review, LXIII(6-7): 1141-1193.

- Ambrosini Gaspare, 1944, Autonomia regionale e federalismo: Austria, Spagna, Germania, URSS, Edizioni italiane, Roma.

- Baldi Brunetta, 2003, Stato e territorio. Federalismo e decentramento nelle democrazie contemporanee, Laterza, Roma and Bari.

- Brennan, William J., Jr., 1977, 'State Constitutions and the Protection of Individual Rights', in Harvard Law Review, XC(3): 489-504.

- Cardone Andrea, 2006, 'Gli organi di garanzia statuaria tra suggestioni del diritto comparato, "paletti" della Corte costituzionale e apodittiche ricostruzioni del sistema delle fonti', in Carli Massimo, Carpani Guido and Siniscalchi Arturo (eds.), I nuovi statuti delle Regioni ordinarie. Problemi e prospettive, il Mulino, Bologna, 277-302.

- Carrillo Marc, 2008, 'Costituzione e Statuto: la garanzia dei diritti da parte degli organi consultivi nell'ambito delle Autonomie', in Le Regioni, XXXVI(6): 1125-1155.

- Cassese Sabino, 2010, 'Lo stato presente del diritto amministrativo italiano', in Rivista trimestrale di diritto pubblico, LX(2): 389-400.

- Cassese Sabino, 2011, 'Auf der gefahrenvollen Straße des öffentlichen Rechts. La "rivoluzione scientifica" di Vittorio Emanuele Orlando’, in Materiali per una storia della cultura giuridica, XLI(2): 305-318.

- Delledonne Giacomo, 2011, 'Speaking in Name of the Constituent Power: the Spanish Constitutional Court and the New Catalan Estatut, in Perspectives on Federalism, III(1): N1-14.

- Delledonne Giacomo and Martinico Giuseppe, 2011, 'Legal Conflicts and Subnational 
Constitutionalism', EUI Working Paper LAW 2011/03, available at http://cadmus.eui.eu/bitstream/handle/1814/16214/LAW 2011 03.pdf?sequence=1.

- Dietlein Johannes, 1995, 'Die Rezeption von Bundesgrundrechten durch Landesverfassungsrecht. Zum Verhältnis der Bundesgrundrechte zu den durch Rezeption geschaffenen Grundrechten der Länder', in Archiv des öffentlichen Rechts, CXX(1): 1-31.

- Dinan John, 2007, 'Foreword: Court-Constraining Amendments and the State Constitutional Tradition', in Rutgers Law Journal, XXXVIII(4): 983-1039.

- $\quad$ Elazar Daniel J., 1999, 'Foreword: The Moral Compass of State Constitutionalism', in Rutgers Law Journal, XXX(4): 849-870.

- Falcon Giandomenico, 2010, 'La giustizia amministrativa e gli altri federalismi', in Diritto pubblico, XVI(1-2): 557-584.

- Fasone Cristina, 2012, 'Which Role for Regional Assemblies in Regional States? Italy, Spain and United Kingdom in Comparative Perspective', in Perspectives on Federalism, IV (forthcoming).

- $\quad$ Favoreu Louis, 1996, Les cours constitutionnelles, 3rd edition, Presses universitaires de France, Paris.

- Fercot Céline, 2008, 'Diversity of Constitutional Rights in Federal Systems. A Comparative Analysis of German, American and Swiss Law', in European Constitutional Law Review, IV(4): 302-324.

- $\quad$ Fossas Espadaler Enric, 2011, 'El control de constitucionalitat dels Estatuts d'Autonomia', in Revista catalana de dret públic, XXVI, issue no. 43: 21-51.

- Gardner James A., 2008, 'In Search of Sub-National Constitutionalism', in European Constitutional Law Review, IV(4) : 325-343.

- Garrido Moyol Vicente, 2011, 'Los consejos jurídicos consultivos en la experiencia regional española', in Le istiturioni del federalismo, XXXII(3): 637-658.

- Ginsburg Tom and Posner Eric A., 2010, 'Subconstitutionalism', in Stanford Law Review, LXII(6): 1583-1628.

- Häberle Peter, 1993, 'Die Verfassungsbewegung in den neuen Bundesländern', in Jabrbuch des öffentlichen Rechts, LI: 69-92.

- Häberle Peter, 2008, 'Neueste Schweizer Kantonsverfassungen - eine Einführung mit Dokumentationen', in Jabrbuch des öffentlichen Rechts, LVI: 278-477.

- Hernández Antonio M., 2010, Judicial Federalism and the Protection of Fundamental Rights in Argentina', in Rutgers Law Journal, XLI(4): 907-930.

- Heuschling Luc, 2008 'Wissenschaft vom Verfassungsrecht: Frankreich', in von Bogdandy Armin, Cruz Villalón Pedro and Huber Peter M. (eds.), Handbuch Ius Publicum Europaeum, vol. 2, Offene StaatlichkeitWissenschaft vom Verfassungsrecht, C.F. Müller, Heidelberg, 491-524.

- Komesar Neil K., 1988, 'A Job for the Judges: The Judiciary and the Constitution in a Massive and Complex Society’, in Michigan Law Review, LXXXVI(4): 657-721.

- $\quad$ Loughlin Martin, 2010, Foundations of Public Law, Oxford University Press, Oxford.

- Lupo Nicola, 2011, 'Gli organi di garanzia statutaria, i metodi della legislazione e i Consigli regionali', in Le istiturioni del federalismo, XXXII(3): 623-635.

- Martinico Giuseppe, 2011, 'Constitutional Failure or Constitutional Odyssey? What Can We Learn from Comparative Law?', in Perspectives on Federalism, III(1): E 51-77.

- $\quad$ Maurer Hartmut, 2007, Staatsrecht, 5th edition, C.H. Beck, München.

- Napoli Cristina, 2008, 'Gli organi di garanzia statutaria nella legislazione regionale', in Le istituzioni del federalismo, XXIX(2): 167-195.

- Neuborne Burt, 2007, 'Hommage à Louis Favoreu', in International Journal of Constitutional Law, V(1) : $17-27$.

- Pierandrei Franco, 1962, 'Corte costituzionale', in Enciclopedia del diritto, vol. X, Giuffrè, Milano, 8741036.

- Pierdominici Leonardo, 2011, "Constitutional Adjudication and the "Dimensions" of Judicial Activism. Legal and Institutional Heuristics', STALS Working Paper, no. 3/2011, available at http://stals.sssup.it/files/Pierdominici 3 2011.pdf.

- $\quad$ Piperata Giuseppe, 2011, 'Gli organi di garanzia statutaria nel "nuovo" sistema regionale italiano', in Rivista trimestrale di diritto pubblico, LXI(2): 381-429. 
Pizzorusso Alessandro, 1981, 'Articolo 134', in Branca Giuseppe (ed.), Commentario della Costiturione, Zanichelli-Foro Italiano, Bologna-Roma, 1-143.

- Pizzorusso Alessandro, 2006, 'Il diritto costituzionale e il genere letterario "note a sentenza", in Pace Alessandro (ed.), Corte costituzionale e processo costituzionale: nell'esperienza della rivista "Giurisprudenza costituzionale” per il cinquantesimo anniversario, Giuffrè, Milano, 855-860.

- Pizzorusso Alessandro, 2007, 'Giustizia costituzionale (diritto comparato)', in Enciclopedia del diritto, Annali, vol. I, Giuffrè, Milano, 669-715.

- Popelier Patricia, 2012, 'The Need for Sub-National Constitutions in Federal Theory and Practice: The Belgian Case', in Perspectives on Federalism, IV (forthcoming).

- $\quad$ Romboli Roberto, 2005, 'Articolo 57', in Caretti Paolo, Carli Massimo and Rossi Emanuele (eds.), Statuto della Regione Toscana. Commentario, Giappichelli, Torino, 283-293.

- $\quad$ Rozek Jochen, 1994, 'Landesverfassungsgerichtsbarkeit, Landesgrundrechte und die Anwendung von Bundesrecht. Landesverfassungsgerichtliche Kontrolle der Anwendung von Bundesrecht durch Landesgerichte am Maßstab der Landesgrundrechte?', in Archiv des öffentlichen Recht, CXIX(3): 450-483.

- Russell Peter H., 2009, 'The Unrealized Benefits of Canada's Unfederal Judicial System', in Anastakis Dimitry and Bryden P.E. (eds.), Framing Canadian Federalism: Historical Essays in Honour of John T. Saywell, University of Toronto Press, Toronto, 255-271.

- $\quad$ Starck Christian, 1993, 'Der Honecker-Beschluß des Berliner VerfGH. Anwendung von Bundesprozeßrecht durch Landesgerichte unter Kontrolle der Landesverfassungsgerichte?', in JuristenZeitung, XLVIII(5): 231-234.

- $\quad$ Starck Christian, 2008, 'Verfassungsgerichtsbarkeit der Länder', in Josef Isensee and Paul Kirchhof (eds.), Handbuch des Staatsrechts der Bundesrepublik Deutschland, vol. VI, Bundesstaat, 3rd edition, C.F. Müller, Heidelberg, 317-382.

- $\quad$ Starck Christian and Stern Klaus (eds.), 1983, Landesverfassungsgerichtsbarkeit, Nomos, Baden-Baden.

- Tarr G. Alan, 1994, 'The Past and Future of the New Judicial Federalism', in Publius: The Journal of Federalism, XXIV(2): 63-79.

- Tarr G. Alan, 2009, 'Subnational Constitutions and Minority Rights: A Perspective on Canadian Provincial Constitutionalism', in Rutgers Law Journal, XL(4): 767-792.

- Tietje Christian, 1999, 'Die Stärkung der Verfassungsgerichtsbarkeit im föderalen System Deutschlands in der jüngeren Rechtsprechung des BVerfG', in Archiv des öffentlichen Rechts, CXXIV(2): 282305.

- Tornos Mas Joaquín, 2010, 'El Consell de Garanties Estatutàries', in Revista catalana de dret públic, Especial sentència l'Estatus, sobre available at http://www10.gencat.net/eapc revistadret/recursos interes/especial $\% 20$ estatut/documents $\% 20$ especial $\% 2$ 0estatut/document.2010-07-15.7236299341/ca.

- Vintró Castells Joan, 2010, 'Els dictàmens vinculants del Consell de Garanties Estatutàries', in Revista catalana de dret públic, Especial sentència sobre l'Estatut, available at http://www10.gencat.net/eapc revistadret/recursos interes/especial $\% 20$ estatut/documents $\% 20$ especial $\% 2$ 0estatut/document.2010-07-15.7236299341/ca.

- Williams Robert F., 1998, 'Justice Brennan, the New Jersey Supreme Court, and State Constitutions: The Evolution of a State Constitutional Consciousness', in Rutgers Law Journal, XXIX(4): 763-792.

- Williams Robert F., 2009, The Law of American State Constitutions, Oxford University Press, Oxford.

- Zaccaria Roberto (ed.), 2011, Fuga dalla legge? Seminari sulla qualità della legislazione, Grafo, Brescia.

- Zierlein Karl-Georg, 1995, 'Prüfungs- und Entscheidungskompetenzen der Landesverfassungsgerichte bei Verfassungsbeschwerden gegen landesrechtliche Hoheitsakte, die auf Bundesrecht beruhen oder in einem bundesrechtlich geregelten Verfahren ergangen sind', in Archiv des öffentlichen Rechts, CXX(2): 205-247. 